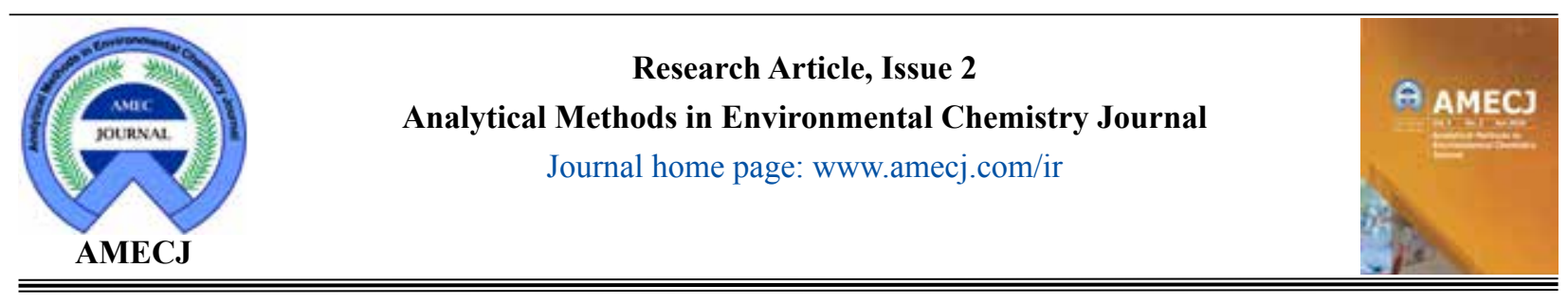

\title{
Separation and determination of mercury from nail and hair in petrochemical workers based on silver carbon nanotubes by microwave-assisted headspace sorbent trap
}

\author{
Daniel Soleymania, Sahar Zargari ${ }^{\mathrm{b}}$ and Ali Faghihi-Zarandia," \\ a Occupational Health Engineering Department, Modeling in Health Research Center, Institute \\ for Futures Studies in Health,Kerman University of Medical sciences, Kerman, Iran \\ ${ }^{b}$ Software Engineer, Statistical sciences and engineering, Department of Web development and software engineering, \\ Research Institute of Petroleum Industry, Tehran, Iran
}

\section{A R T I C L E I N F O : \\ Received 29 Feb 2020 \\ Revised form 17 Apr 2020 \\ Accepted 14 May 2020 \\ Available online 27 Jun 2020}

Keywords:

Mercury,

Nail and Hair,

Silver multi-walled carbon

nanotubes,

Microwave-assisted headspace removal

\section{A B S T R A C T}

In this work, the occupational analytical chemistry was developed for determination of chronic exposure of mercury in nail and hair in petrochemical workers (Age: 30-50, Men). By experimental procedure, $100 \mathrm{mg}$ of hair and nail of workers was prepared by washing / grinding and then the powder was dried in oven for $20 \mathrm{~min}$ at $95^{\circ} \mathrm{C} .20 \mathrm{mg}$ of hair or nail samples added to reagents $\left(\mathrm{HNO}_{3} / \mathrm{H}_{2} \mathrm{O}_{2} ; 5: 1\right)$ in polyethylene tube (PET) of microwave digestion and the mercury in resulting solution was removed with silver nanoparticles pasted on multi-walled carbon nanotubes (Ag-MWCNTs) which were placed in head space of separator. After microwave digestion for $25 \mathrm{~min}$, the mercury vapor was removed by $A g-M W C N T s$ as the headspace sorbent trap (HSST) under hood conditions. Finally, the mercury in sorbent was online determined by cold vapor atomic absorption spectrometry (CV-AAS) after heat process at $250^{\circ} \mathrm{C}$ in presence of Ar gas. The capacity adsorptions of $\mathrm{Ag}$ $M W C N T S$ and $M W C N T S$ for mercury removal from air were obtained $205.4 \mathrm{mg} \mathrm{g}^{-1}$ and $63.7 \mathrm{mg} \mathrm{g}^{-1}$, respectively. The mean of mercury in nail and hair in workers and healthy peoples was achieved $\left(15.2 \pm 3.7 \mu \mathrm{g} \mathrm{g}^{-1}\right.$; $\left.11.6 \pm 2.6 \mu \mathrm{g} \mathrm{g}^{-1}\right)$ and $\left(0.16 \pm 0.05 \mu \mathrm{g} \mathrm{g}^{-1} ; 0.24 \pm 0.03 \mu \mathrm{g} \mathrm{g}^{-1}\right)$, respectively $(\mathrm{RSD}<5 \%)$. The validation of method was done by certified reference material (CRM).

\section{Introduction}

Mercury, as a trace heavy metal element, is the only common metal which is liquid at ordinary temperatures and has a high vapor pressure [1]. Atmospheric mercury is present in three forms: metallic or elemental mercury $(\mathrm{Hg} 0)$, oxidized or inorganic mercury $\left(\mathrm{Hg}^{2+}\right)$ and particulate-bound mercury with organic materials such as methyl (R$\mathrm{Hg}$ ) [2]. Each of these forms has different impacts

\footnotetext{
${ }^{*}$ Corresponding Author: Ali Faghihi-Zarandi

Email: alifaghihi60@yahoo.com

https://doi.org/10.24200/amecj.v3.i02.99
}

on health surveillance and requires different countermeasures to avoid exposure. $\mathrm{Hg} 0$ is oxidized to inorganic forms of $\mathrm{Hg}^{2+}$, when entering the atmosphere. Elemental mercury in its gaseous form is the main form of mercury in the atmosphere with atmospheric lifetime of approximately 6-24 months [3]. It is a pollutant of great concern due to its volatility, toxicity, persistence, and bioaccumulation in the environment and its neurotoxic impact on human health $[4,5]$. Mercury vapors are well absorbed into blood through the lungs (approximately 80\%) and can easily cross the blood-brain barrier as a lipid-soluble substance in human body tissues such as brain and 
renal [6]. Chlor-alkali factories using mercury metal as a liquid electrode in the manufacturing of chlorine (Cl2) and sodium hydroxide $(\mathrm{NaOH})$ by electrolysis release of the mercury vapor in air and so, it causes to disease in workers by exposure of the workers to mercury [7]. Chlor-alkali plants (CAP) which use mercury $(\mathrm{Hg})$ in electrolytic cell manufacture has been identified as one of the main sources of $\mathrm{Hg}$ pollution in environmental air. Although alternative methods were established to replace the Hg-cell process, many older plants are still in operation in some undeveloped areas. In addition, many amounts of mercury enter to environment by different sources such as chemical factories, petrochemical activity, volcanoes, forest fires, and fossil fuels [8]. Bioaccumulation of mercury in the human body changes the normal cell/tissues/organs and cause to cancer. It can damage the physiological activities of the human body especially in the brain and renal, even at very low concentrations of mercury [9]. The primary target for $\mathrm{Hg}$ exposure is the central nervous system (CNS) and then, it can also damage many organ systems such as liver and renal through its ephemeral and residual systemic distribution [10] Finally, the chronic mercury exposure can be damaged the cells of kidney [11] and central nervous system (CNS) [12]. In addition, the other organs/systems such as the immune system, reproduction and cardiovascular system can also be affected by mercury exposure [13]. The mercury exposure has adverse health effect in human body and can depend on the form of the mercury, time and dose of exposure [14]. Acute, highdose exposure to elemental mercury vapor may cause to pneumonitis. At low levels, the acute lung injury, insomnia, headaches, disturbances in sensations and changes in nerve responses is obtained and then, the chronic inhalation cause to many problems include, tremor, gingivitis, particularly irritability, depression, short-term memory loss, fatigue, anorexia, and sleep disturbance [15]. In the general population, the total blood mercury concentration is due mostly to the dietary intake of organic forms, particularly methyl mercury and urinary mercury consists mostly of inorganic mercury forms [15]. Several studies identified a significant positive association between mercury in hair samples and hypertension (blood pressure); whereby the exposure dose is an important factor for determining the toxic effects of mercury [16]. Hair mercury concentration as a biomarker of organic and inorganic mercury exposure can be provided the information over a definable period of time, based upon sequential analyses of hair segments, to represent both the magnitude and timing of past exposure. However, the mercury analysis in hair have two problems. The first concerns the origin of the measured elements, and the second concerns the biological significance that may be given to the level of the elements. Unlike hair, total blood mercury levels also include inorganic mercury, which may be of importance in certain contexts. It is generally considered the appropriate indicator of the absorbed dose. Urinary mercury concentrations are widely used as a biomarker of mercury exposure from elemental or inorganic mercury [17]. Note, the inorganic mercury can be changed to organic forms by high concentration of mercury or chronic exposure of mercury. It is very important to develop a novel analytical method for determination of heavy metals in environment and biological samples for monitoring the severity of heavy metal pollution. At the present time, the most well-known methods for detecting heavy metals are atomic absorbance spectrometry (AAS) [18], atomic fluorescence spectrometry (AFS) [19], electrochemical analysis, inductively coupled plasma (ICP) [20], high performance liquid chromatography (HPLC) [21] and capillary electrophoresis [22]. However, these methods generally need a sample preparation or extraction procedure [23]. Recently, the cold vapor atomic absorption spectrometry (CVAAS) was used as a favorite analytical technique for mercury analyses in various types of samples [24], but it has been necessary to develop with preconcentration methods that allow mercury determination at ultratrace levels [25]. Liquid-liquid extraction/micro extraction (LLE/LLME) and solid-phase extraction/ micro solid-phase extraction (SPE\&MSPE) are the most commonly employed methods to achieve the separation and preconcentration of metal ions [26-28]. In this study, the chronic exposure of mercury in nail and hair of petrochemical workers was determined 
by microwave-assisted headspace removal procedure (MAHR). By procedure, the microwave based on silver nanoparticles passed on multi-walled carbon nanotubes (Ag-MWCNTs) was used as head space removal and mercury concentration was determined by CV-AAS.

\section{Experimental}

\subsection{Instrumental}

Mercury was measured by an atomic absorption spectrometer (AAS, GBC 932, Australia) equipped with a flow injection cold vapor accessory (FI-CV). The background correction with a deuterium-lamp and hollow-cathode lamp of mercury was used. The circulating cooling unit (CCU) caused to generation of vapour of mercury in cold conditions. NaBH4 / $\mathrm{NaOH}$ or $\mathrm{SnCl} 2 / \mathrm{HCl}$ was used as reduction agents for generating of mercury hydride which was moved to liquid - gas separator by Ar. The conditions of FI-CVAAS were shown in Table 1 . The $\mathrm{pH}$ ranges in liquid phase were adjusted and determined by a Metrohm pH meter (744, Switzerland). The multiwave microwave system (MMS, Anton Paar 3000, Austria) was used for digestion of hair and nail samples which was converted the organic mercury to inorganic mercury. Anton Paar's 8-position rotor (8SXQ80) and respective reaction vessels individually equipped with variable temperature and ultraviolet (UV) radiations. The temperature and pressure of MMS were $220^{\circ} \mathrm{C}$ and 35 bar, respectively.

Table 1. The conditions of mercury determination by FI-CVAAS with closed cell

\begin{tabular}{ll}
\hline Features & Value \\
\hline Linear range & $0.5-65 \mu \mathrm{g} \mathrm{L}^{-1}$ \\
Working range & $0.5-150 \mu \mathrm{g} \mathrm{L}^{-1}$ \\
Wavelength & $253.7 \mathrm{~nm}$ \\
Lamp current & $4.0 \mathrm{~mA}$ \\
Slit & $0.5 \mathrm{~nm}$ \\
Mode & Peak Area surface \\
HCl carrier solution $37 \%$ & $3.4 \mathrm{~mol} \mathrm{~L}-1$ \\
NaBH4 reducing agent, $\%(\mathrm{~m} / \mathrm{v})$ & $0.6(0.5 \% \mathrm{NaOH})$ \\
Argon flow rate & $15.0 \mathrm{~mL} \mathrm{~min}^{-1}$ \\
Sample flow rate & $4.0 \mathrm{~mL} \mathrm{~min}{ }^{-1}$ \\
Reagent flow rate & $\mathrm{mL} \mathrm{min}{ }^{-1}$ \\
\hline
\end{tabular}

\subsection{Reagents}

All reagents with high purity as an analytical grade were purchased from Merck (Darmstadt, Germany). All samples were prepared with the deionized water (DW) from Millipore water system (USA). The standard stock solution of inorganic mercury (1000 mg L-1 Hg(II) in 1\% nitric acid) was purchased from Fluka, Switzerland. The working standard solutions were prepared daily by diluting of standard solutions with DW. The solutions were freshly prepared and stored just in a fridge $\left(4{ }^{\circ} \mathrm{C}\right)$ to prevent decomposition. First, $0.6 \%(\mathrm{w} / \mathrm{v})$ $\mathrm{NaBH} 4$ solution was prepared daily by dissolving in $0.5 \%(\mathrm{w} / \mathrm{v})$ sodium hydroxide $(\mathrm{NaOH})$ and used as a reducing agent. The glassware and plastics of laboratory were cleaned by nitric acid $(15 \%, \mathrm{v} / \mathrm{v})$ for at least $12 \mathrm{~h}$ and then washed with DW. Silver nitrate, ammonia, formalin, and ethanol were purchased from Merck Company (Germany).

\subsection{Synthesis of AgNPs-MWCNTs}

The silver nanoparticles passed on MWCNTs have prepared. First, the mixture of MWCNTs $(10 \mathrm{mg})$ in $100 \mathrm{~mL}$ of DW solution was prepared and then, $0.3 \mathrm{~g}$ of T-X100 as a surfactant was dispersed in mixture at $300 \mathrm{rpm}$ stirring speed. The $0.5 \mathrm{~g}$ of silver nitrate was added to the mixture (MWCNTs/ AgNO3/TX-100/DW) without heat in same stirring speed (300 rpm). Finally, $2 \mathrm{~mL}$ of the ammonia solution was added to above solution and diluted with DW up to $0.5 \mathrm{~L}$ by stirring at 15 minute. Then, $12 \mathrm{~mL}$ of formalin as a reducing agent was added to product in $5 \mathrm{~min}$ and by increasing the speed of stirring (600-800 rpm), the AgNPs (20-100 nm) were coated on the MWCNTs. For cleaning of the MWCNTs from $\mathrm{CH}_{2} \mathrm{O}$ and $\mathrm{NH}_{3}$, the product was washed with DW for 10 times. For preventing of silver oxidation, the product (AgNPs-MWCNTs) washed with Ethanol or increasing temperature up to $180^{\circ} \mathrm{C}$.

\subsection{Procedure}

As Figure 1, $20 \mathrm{mg}$ of hair or nail samples and reagents $\left(\mathrm{HNO}_{3} / \mathrm{H}_{2} \mathrm{O}_{2} ; 5: 1\right)$ was put into PET of microwave digestion at UV/@220 ${ }^{\circ} \mathrm{C}$ for $30 \mathrm{~min}$. 
After digestion, the resulting solution was diluted with $\mathrm{DW}$ up to $10 \mathrm{~mL}$ mixed with reducing reagents $\left(\mathrm{NaBH}_{4} / \mathrm{NaOH}\right)$ in mixer. Then, the hydride form of mercury in liquid phase was generated by reaction loop before moved to separator by flowrate of $100 \mathrm{ml}$ min-1. As ultra-trace mercury (sub ppb), the mercury was preconcentrated by Ag-MWCNTs trap in head space of separator. Finally, the concentration mercury was online determined by closed cell FI-CV-AAS after thermal desorption by heat accessory at $185^{\circ} \mathrm{C}$ in presence of $\mathrm{Ar}$ gas. The peak area of absorption was calculated as concentration of mercury in nail or hair samples by Avanta software of FI-CV-AAS. The conditions of procedure were shown in Table 2.

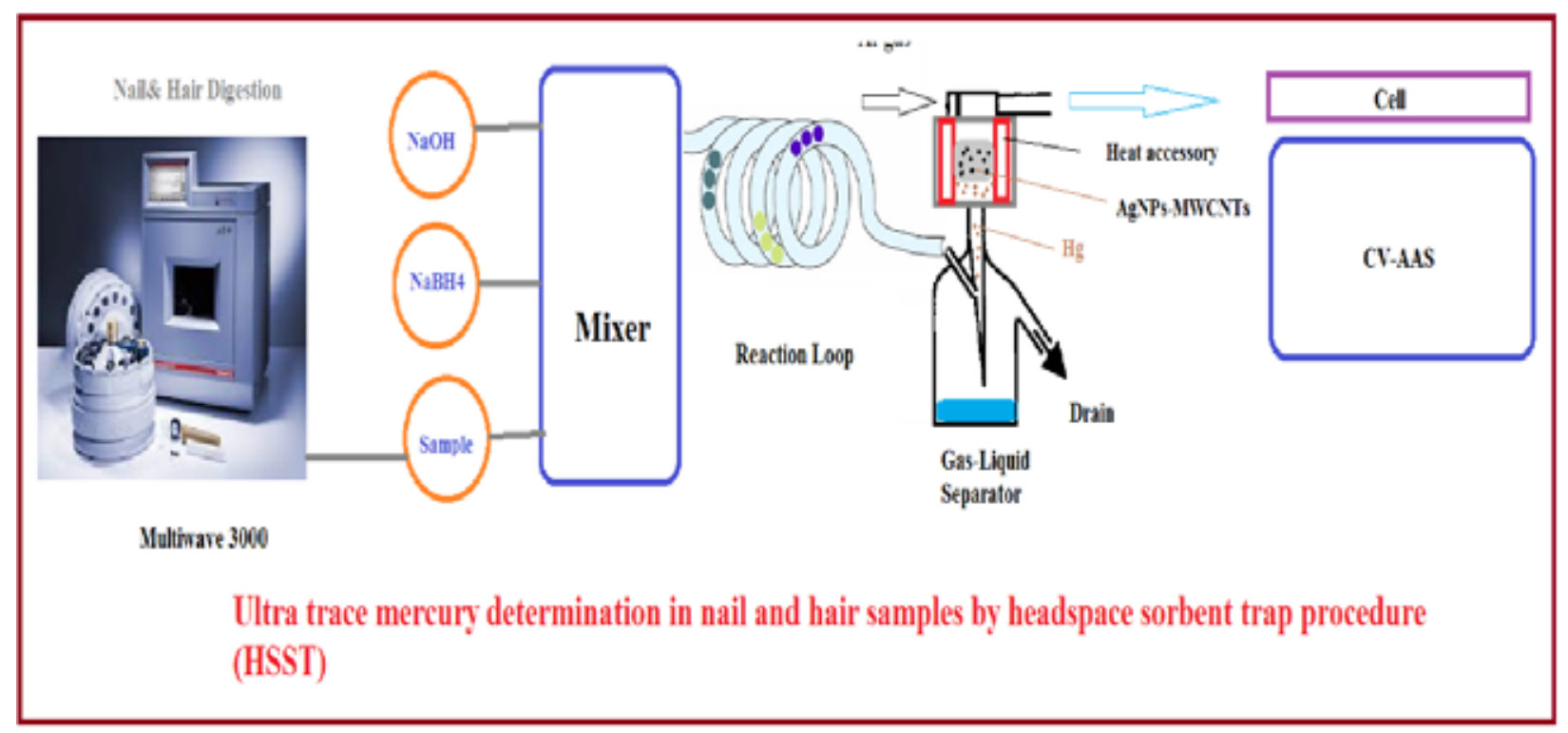

Fig.1. Determination mercury in nail and hair based on Ag-MWCNTs by HSST method

Table 2. The conditions of the headspace sorbent trap (HSST) method in nail, hair and water samples by Ag-MWCNTs sorbent

\begin{tabular}{lll}
\hline Parameter & Nail/Hair sample & Water sample \\
\hline $\mathrm{PF}^{\mathrm{a}}$ & 32.2 & 35.1 \\
$\mathrm{LOD}^{\mathrm{b}}\left(\mathrm{n}=10, \mathrm{ng} \mathrm{L}^{-1}\right)$ & 5.3 & 4.5 \\
$\mathrm{RSD}^{\mathrm{c}}(\%)$ & 2.4 & 1.9 \\
Linear range $\left(\mu \mathrm{g} \mathrm{L}^{-1}\right)$ & $0.015-2.1$ & $0.013-1.85$ \\
Working range $\left(\mu \mathrm{g} \mathrm{L}^{-1}\right)$ & $0.015-4.7$ & $0.013-4.4$ \\
Correlation coefficient & 0.9991 & 0.9995 \\
\hline
\end{tabular}

${ }^{\mathrm{a}}$ Preconcentration factor, ${ }^{\mathrm{b}}$ Limit of detection,

${ }^{\mathrm{c}}$ Relative standard deviation. 


\section{Results and Discussion}

As chronic exposure of mercury in nail and hair in petrochemical workers, the novel method based on Ag-MWCNTs sorbent was used for mercury determination by microwave-headspace sorbent trap (MW-HSST) procedure. For optimization recovery, the parameters such as, temperature, flowrate, adsorption capacity was studied. On the other hand, validation of proposed method was achieved based on spiking samples and Microwave digestion coupled to gold MC-3000 as ultra-trace analyzer of mercury (ppt). Based on results, the recovery of Ag-MWCNTs and MWCNTs sorbents was obtained 38.5 and 98.3, respectively. The recoveries in Ag-MWCNTs and MWCNTs sorbents were determined by MW-HSST procedure (equation I). Furthermore, the adsorption capacity of sorbents was considered by equation of II.

$$
\begin{aligned}
& \text { Recovery }=\frac{a}{b} \times 1 \cdots \\
& \text { Adsorption Capacity }=\frac{\left(C^{\prime}-C^{\top}\right) \times v}{m}
\end{aligned}
$$

As equation $I$, a is the primary concentration of mercury and $b$ is the final concentration of mercury, the adsorption capacity $\left(\mathrm{mg} \mathrm{g}^{-1}\right)$ was shown in equation of II and and (mg L $\left.\mathrm{L}^{-1}\right)$ are before and after adsorption of mercury concentration by $\mathrm{Ag}$ MWCNTs, V is the air volume as flowrate and (g) is the mass of Ag-MWCNTs.

\subsection{Characterization}

The specific surface area (SBET) of Ag-MWCNT and MWCNTs were obtained from the BET equation at $20^{\circ \mathrm{C}}$. Decreasing of BET surface area of Ag-MWCNT in comparison with initial MWCNT was due to the grafting of silver nanoparticles on walls of MWCNTs.

The SEM micrographs of MWCNTs and AgMWCNTs were shown in Figure $2 \mathrm{a}$ and $2 \mathrm{~b}$. The diameter of MWCNTs and Ag-MWCNTs is approximately between 30-100 $\mathrm{nm}$. The XRD patterns of MWNTs and Ag-MWCNTs were shown in Figure 3. The TEM micrographs (Germany, Philips CM30, $250 \mathrm{kV}$ ) showed the morphology of the MWCNTs and Ag-MWCNTs particles. Nano particles of MWNTs and Ag-MWCNTs were dissolved in ethanol by shaking for $15 \mathrm{~min}$ and a drop of the ethanol was used by TEM instrument. The similar TEM micrographs for MWNTs and Ag-MWCNTs were obtained about $40 \mathrm{~nm}$ (Fig. 4a and $4 b)$.

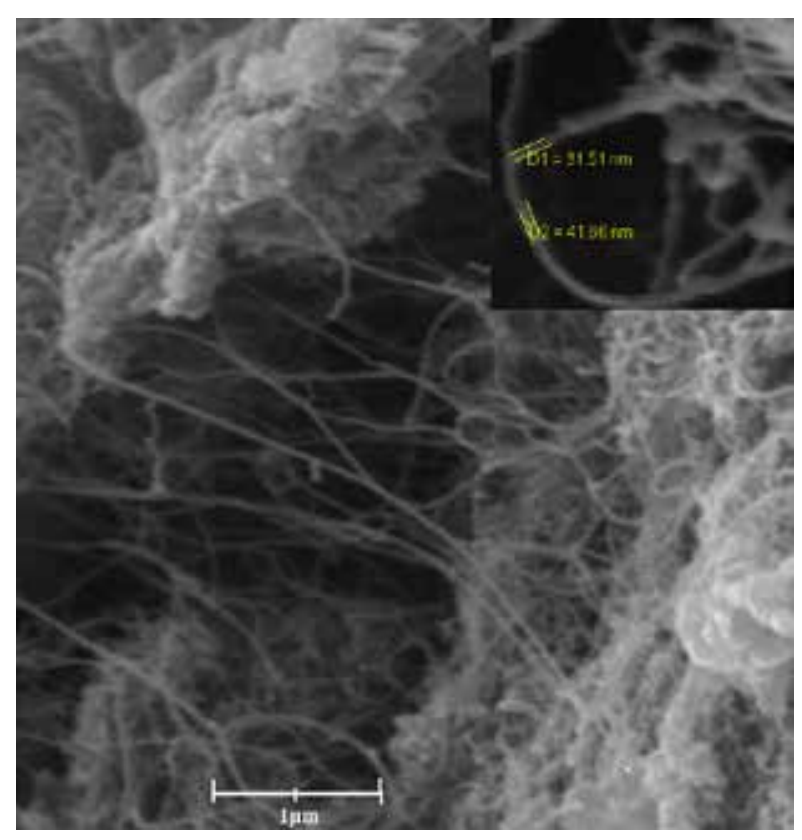

Fig. 2a. The SEM of MWCNTs.

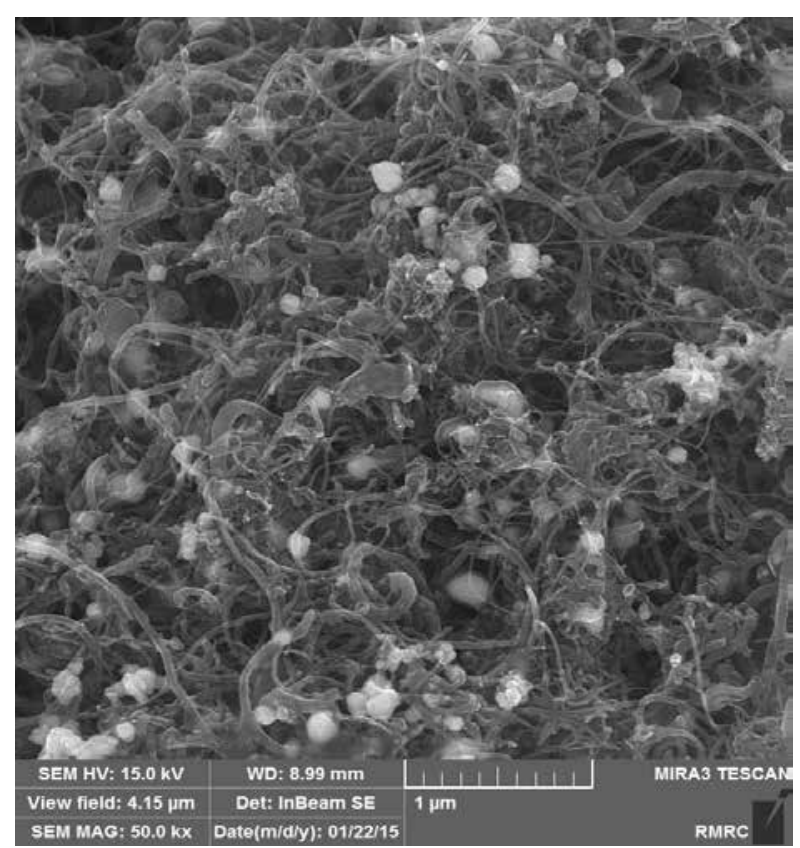

Fig. 2b. The SEM of Ag-MWCNTs. 


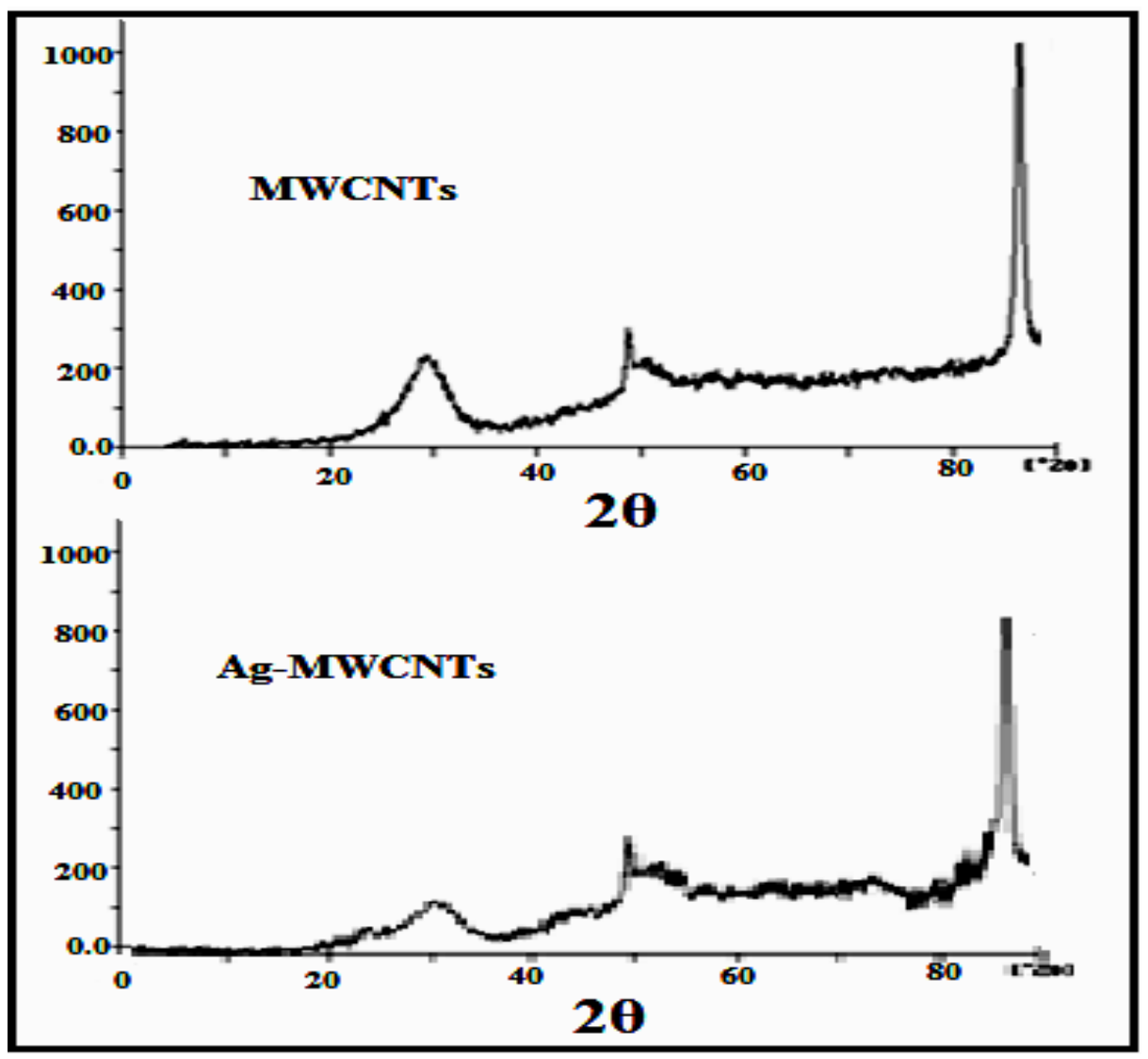

Fig. 3. The XRD of MWCNTs and Ag-MWCNTs

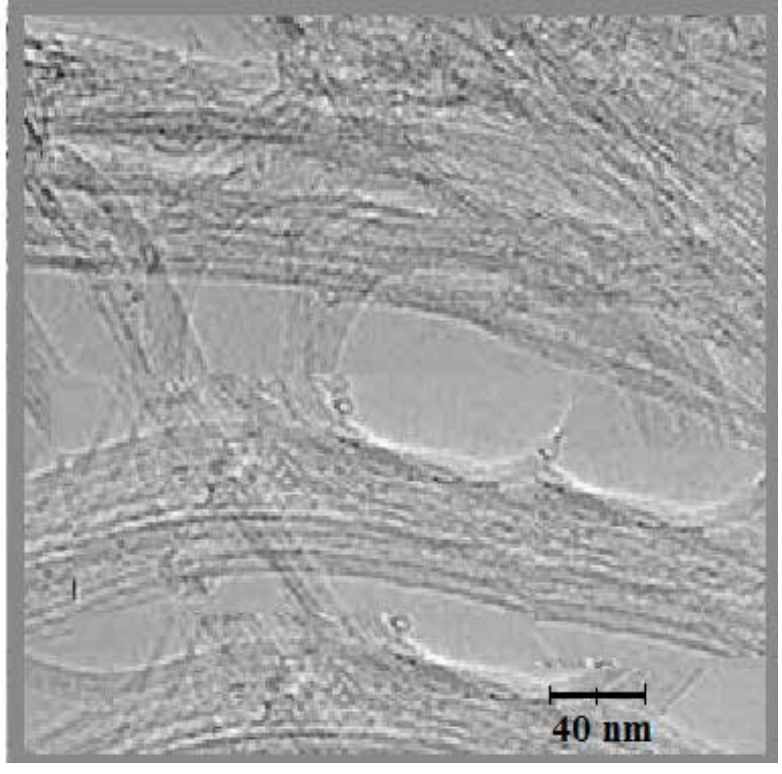

Fig. 4a. The TEM of MWCNTs.

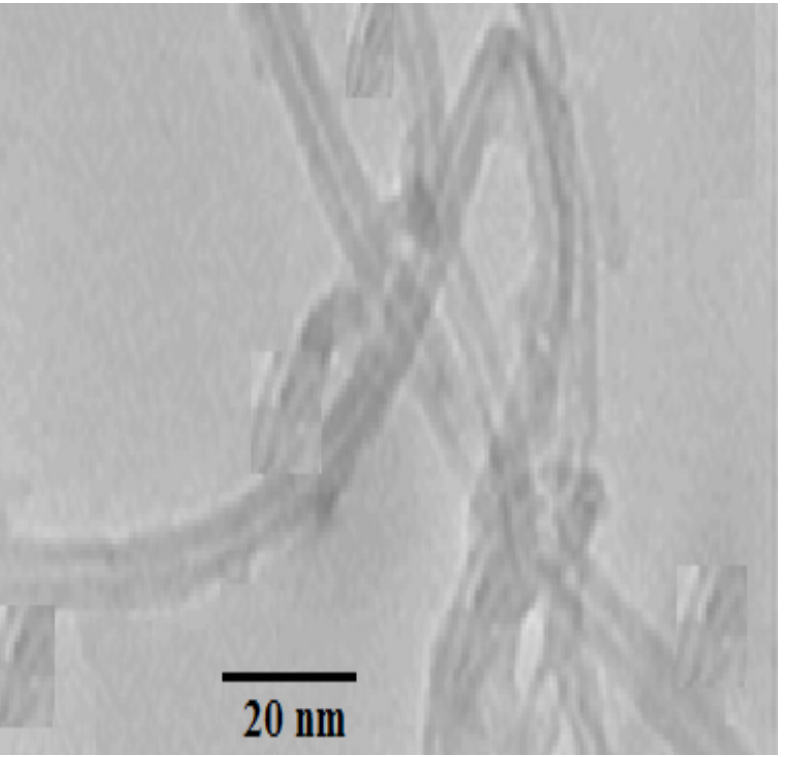

Fig. 4b. The TEM of Ag-MWCNTs 


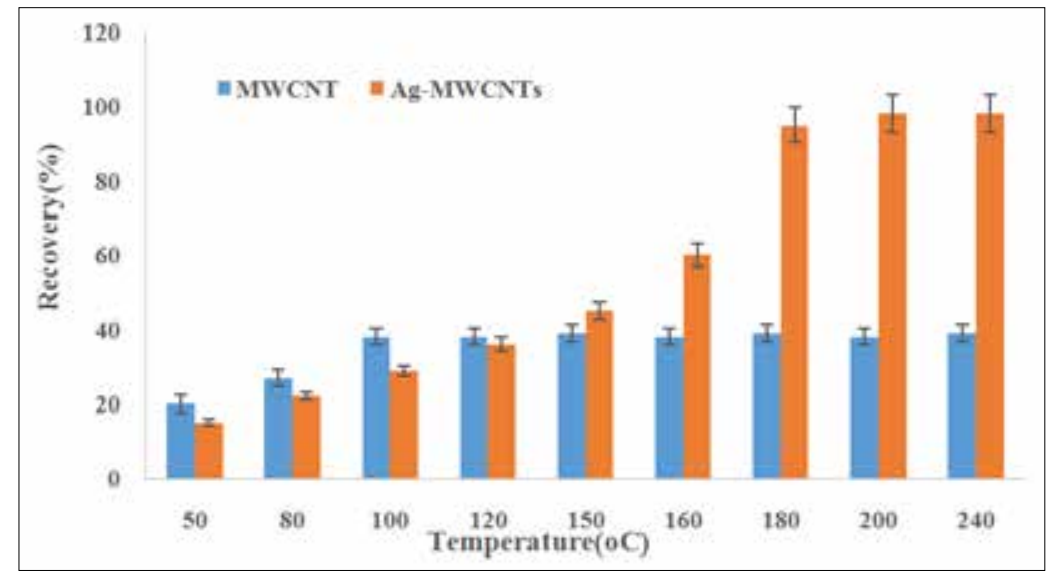

Fig. 5. The effect of temperature on desorption mercury from

Ag-MWCNTs and MWCNTs sorbents by HSST method.

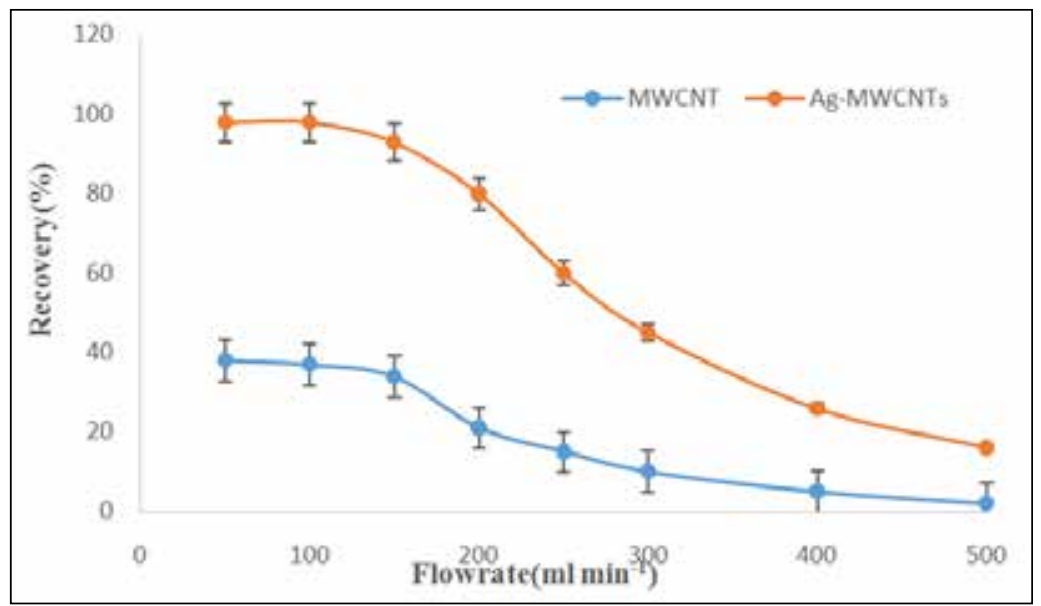

Fig. 6. The effect of flow rate on removal of mercury vapor from liquid phase by Ag-MWCNTs and MWCNTs sorbents

\subsection{Effect of temperature}

The effect of temperature for absorption and desorption mercury by Ag-MWCNTs sorbent was investigated. The temperatures between 20-2000C was studied for procedure. As results, the recovery of Ag-MWCNTs and MWCNTs was decreased in high temperature and the mercury can be desorbed from Ag-MWCNTs and MWCNTs at $185 \mathrm{oC}$ and more than $80 \mathrm{oC}$. The results showed, the optimum temperature for adsorption and desorption mercury from Ag-MWCNTs sorbent was obtained 25-35oC and $1850 \mathrm{C}$ (Fig. 5).

At temperature more than $35 \mathrm{oC}$, the removal efficiency of mercury by Ag-MWCNTs were decreased. Temperature had more effected on mercury removal by Ag-MWCNTs as compared to humidity.

\subsection{Effect of flow rate}

The main factor for adsorption of mercury on AgMWCNTs sorbent was depended on flowrate of Argon gas which was caused to increase interaction $\mathrm{Hg}$ with $\mathrm{Ag}$ as amalgamation form (Ag-Hg). As optimized conditions for removal of mercury by headspace sorbent trap (HSST) method, the flow rates must be evaluated. So, the flow rates between $50-500 \mathrm{~mL}$ min1 were optimized for Ag-MWCNTs and MWCNTs at room temperature. The flow rate was determined by a rotameter accessory in room temperature. In high and low flowrate, the rate of adsorption was reduced and increased, respectively. The results showed that maximum recovery for mercury removal was achieved by Ag-MWCNTs at flowrate $100 \mathrm{ml} \mathrm{min}-1$. Figure 6 showed the effects of flow rate on the removal efficiency of mercury by HSST method. 


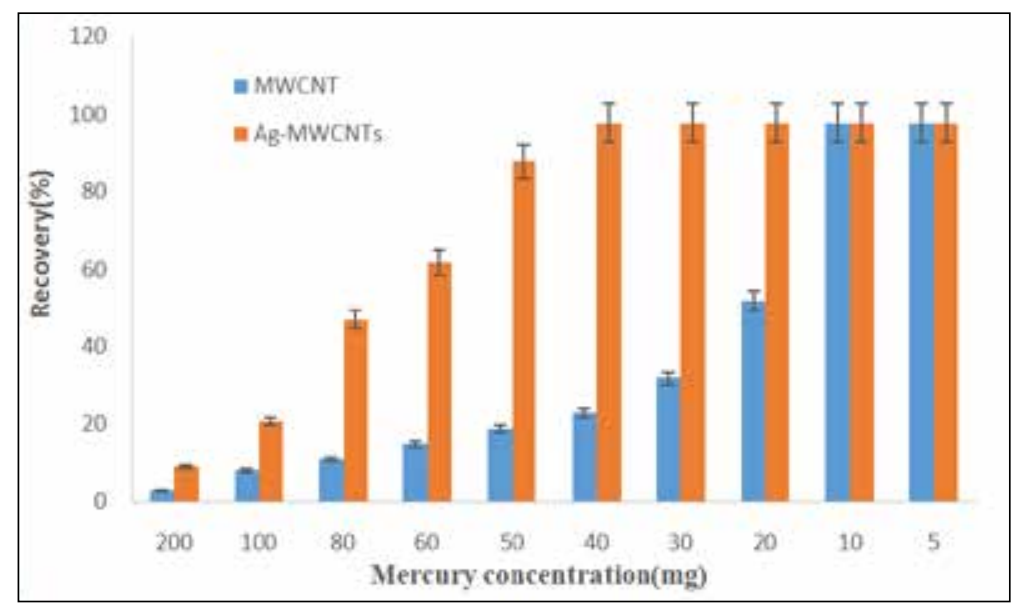

Fig. 7. The absorption capacity of mercury by Ag-MWCNTs and MWCNTs sorbents by HSST method

\subsection{Adsorption capacity}

In this study, the adsorption capacity of mercury by Ag-MWCNTs, and MWCNTs in batch system has obtained $205.4 \mathrm{mg} \mathrm{g}^{-1}, 63.7 \mathrm{mg} \mathrm{g}^{-1}$, respectively which was shown in Figure 7. The closed special vial $(10 \mathrm{~mL})$ was used with $5 \mathrm{~mL}$ of liquid standard mercury value $(100 \mathrm{mg}), 0.2 \mathrm{~g}$ of Ag-MWCNTs, and MWCNTs sorbents in head space of vial and reducing agents which was added by syringe with beside input port. After 5, 10, 15,20 min, the mercury in sorbent determined by CV-AAS. The results showed us, the maximum removal was achieved by Ag-MWCNTs after 15 min. By procedure, the final concentration in sorbent was obtained $41.1 \mathrm{mg}$ of mercury after thermal desorption.

\subsection{Validation}

The accurate and precise results for mercury determination in nail /hair are important factor for human samples. So, the mercury results based on Ag-MWCNTs must be validated by MW-HSST procedure. First, the different concentration of standard mercury solutions from 0.5 to $5 \mu \mathrm{g} \mathrm{L}^{-1}$ was prepared. For validation, the different concentrations of mercury were used for spiking of nail, hair and water samples by Ag-MWCNTs sorbents (Table 3). The removal efficiency of sorbents based on MW-HSST was evaluated. For method validation ICP analyzer was used for nail and hair samples after sample digestion (Table 4). In addition, the removal efficiency of mercury in water and gas phase by different sorbents was compared to MWHSST procedure (Table 5). According to table5, the Ag-MWCNTs have more efficiency than other sorbents.

Table 3. Validation of MW-HSST procedure for total mercury determination in nail, hair and water samples by spiking of real samples

\begin{tabular}{llll}
\hline Sample & Added $\left(\mu \mathrm{g} \mathrm{L}^{-1}\right)$ & Found $\left(\mu \mathrm{g} \mathrm{L}^{-1}\right)$ & Recovery $(\%)$ \\
\hline Human Nail & ------ & $1.43 \pm 0.05$ & ------ \\
\hline & 1.5 & $2.91 \pm 0.12$ & 98.6 \\
\hline Human Nail & ------ & $0.17 \pm 0.01$ & ------ \\
\hline & 0.2 & $0.36 \pm 0.02$ & 95.0 \\
\hline Human Hair & ------ & $1.98 \pm 0.08$ & ------ \\
\hline & 2.0 & $4.02 \pm 0.17$ & 102 \\
\hline Human Hair & ------ & $0.55 \pm 0.02$ & ------ \\
\hline & 0.5 & $1.03 \pm 0.04$ & 95.8 \\
\hline Well Water & ------ & $0.38 \pm 0.01$ & ------ \\
\hline & 0.5 & $0.86 \pm 0.03$ & 96.0 \\
\hline
\end{tabular}


Table 4. ICP analyzer was used for validation of proposed method for mercury determination in nail and hair samples after sample digestion

\begin{tabular}{lllll}
\hline Sample & ICP-MS $\left(\mu \mathrm{g} \mathrm{L}^{-1}\right)$ & Added $\left(\mu \mathrm{g} \mathrm{L}^{-1}\right)$ & Found $\left(\mu \mathrm{g} \mathrm{L}^{-1}\right)$ & Recovery $(\%)$ \\
\hline Nail & $1.24 \pm 0.03$ & ----- & $1.20 \pm 0.05$ & 96.8 \\
\hline & ------ & 1.0 & $2.17 \pm 0.09$ & 97.0 \\
\hline Hair & 0.52 & ------ & $0.54 \pm 0.03$ & 103.8 \\
\hline & ------ & 0.5 & $1.02 \pm 0.04$ & 96.0 \\
\hline
\end{tabular}

Table 5. Comparing of Ag-MWCNTs based on MW-HSST procedure with different sorbents by published method

\begin{tabular}{|c|c|c|c|c|c|}
\hline Sorbents & Matrix & Technique & $\begin{array}{l}\text { Absorption Capacity } \\
\left(\mathrm{mg} \mathrm{g}^{-1}\right)\end{array}$ & Recovery & Reference \\
\hline $\begin{array}{l}\text { Solid-phase extraction } \\
\text { with multiwalled carbon } \\
\text { nanotubes }\end{array}$ & Real waters & Adsorption & $0.70-3.83$ & ---- & [29] \\
\hline $\mathrm{Ag}-\mathrm{CNT}$ & Flue gases & Amalgamation & 9.3 & --- & {$[30]$} \\
\hline $\begin{array}{l}\text { Silver nano particles/ } \\
\text { MGBs }\end{array}$ & Air/Artificial air & $\begin{array}{l}\text { Amalgamation/ } \\
\text { SPGE }\end{array}$ & 91.8 & $98 \%$ & {$[31]$} \\
\hline Mn/zeolite catalyst & Flue gas & $\begin{array}{c}\text { Microwave } \\
\text { assisted catalytic }\end{array}$ & ---- & $35.3 \%$ & {$[32]$} \\
\hline $\begin{array}{l}\text { Porous carbon-supported } \\
\mathrm{CuCl}_{2}\end{array}$ & Gas & ---- & ---- & $98.5 \%$ & {$[33]$} \\
\hline Nano-ZnS & $\begin{array}{c}\text { Coal Combustion } \\
\text { Fuel Gas } \\
\end{array}$ & Adsorption & $497.84\left(\mu \mathrm{g} \cdot \mathrm{g}^{-1}\right)$ & ---- & {$[34]$} \\
\hline nano-ceramic & Flue gas & Chemisorption & ---- & $75.58 \%$ & {$[35]$} \\
\hline $\mathrm{Au} \mathrm{NP}-\mathrm{Al}_{2} \mathrm{O}_{3}$ & Natural Waters & Adsorption & $\left.145(\mu \mathrm{mol} \mathrm{g})^{-1}\right)$ & $97 \%$ & {$[36]$} \\
\hline $\begin{array}{l}\text { Silver/quartz } \\
\text { nanocomposite }\end{array}$ & Aqueous solutions & ---- & 376.3 & $96 \%$ & [37] \\
\hline $\begin{array}{l}\text { magnetic nanoparticles } \\
\text { coated with yam peel } \\
\text { biomass (MNP-YP) }\end{array}$ & Water & Complexation & ---- & $75 \%$ & {$[38]$} \\
\hline Reduced graphene oxide & Water & $\begin{array}{c}\text { SPE/Anodic } \\
\text { Stripping } \\
\text { Voltammetry }\end{array}$ & 77.0 & 96.4 & {$[40]$} \\
\hline Ag-MWCNTs & Nail/Hair & MW-HSST & 205.4 & 98.8 & This work \\
\hline
\end{tabular}

\subsection{Discussion}

Krawczyk et al was used $\mathrm{TiO}_{2}$ nanoparticles (NPs) as adsorbent for preconcentration and determination of mercury species ( $\mathrm{Hg}$ total, $\mathrm{Hg}^{2+}$ and $\mathrm{CH}_{3} \mathrm{Hg}^{+}$) in biological, environmental and water samples. The mercury extracted based on ultrasound-assisted dispersive micro solid-phase extraction(USA
DMSPE) and determined by cold vapor atomic absorption spectrometry (CV AAS). The detection limit of the method for $\mathrm{Hg}^{2+}$ and relative standard deviations (RSD\%) was obtained $4 \mathrm{ng} \mathrm{L}^{-1}$ and 4-20\%, respectively. The mercury was separated from liquid phase with $10 \mathrm{mg}$ of $\mathrm{TiO}_{2}$ at $\mathrm{pH} 7.5$ [39]. In addition, Ma et al showed that the mercaptopropyl 
trimethoxysilane (MPTS) modified on $\mathrm{Fe}_{3} \mathrm{O}_{4} @ \mathrm{SiO}_{2}$ as a magnetic nanoparticles (MNPs) can used for the speciation of mercury in environmental water and human hair samples. The characterization of (MPTS-MNPs) was obtained by Fourier transform infrared spectrometer (FT-IR), transmission electron microscope (TEM) and vibrating sample magnetometer (VSM). In the optimized conditions, the limits of detection (LOD) for $\mathrm{CH}_{3} \mathrm{Hg}^{+}$and total $\mathrm{Hg}$ were achieved 1.6 and $1.9 \mathrm{ng} \mathrm{L}^{-1}$, respectively. This method successfully applied for the speciation of $\mathrm{CH}_{3} \mathrm{Hg}^{+}$and $\mathrm{Hg}^{2+}$ in water and hair samples [40]. A novel $\mathrm{Fe}_{3} \mathrm{O}_{4} @ \mathrm{SiO}_{2} @$ polythiophene magnetic nanocomposite was synthesized by Abolhasani et al. They could determine the $\mathrm{Hg}$ (II) ions in sea food samples. After sample digestion, the mercury was determined by cold vapor atomic absorption spectrometry (CV AAS). Under the optimum condition, the LOD (20 ng L $\left.{ }^{-1}\right)$ and RSD\% (9.2\%) were obtained. The capacity adsorption of $\mathrm{Fe}_{3} \mathrm{O}_{4} @$ $\mathrm{SiO}_{2} @$ polythiophene magnetic nanocomposite was $59 \mathrm{mg} \mathrm{g}^{-1}$ which was lower than our proposed method base on Ag-MWCNTs (184.3 $\mathrm{mg} \mathrm{g}^{-1}$ ) [41]. In other study, Akbar et al was reported a SPE method based on mGO@SiO $@$ 2-MPATD nanocomposite for determination of mercury in the water and seafood samples. The characterization was obtained by FT-IR, SEM, and elemental analysis techniques. After adsorption and elution steps, the concentration of $\mathrm{Hg}$ (II) was measured by CV-AAS. Under the optimized conditions, the limit of detection was $8 \mathrm{ng} \mathrm{L}^{-1}$. The capacity adsorption of $\mathrm{mGO} @ \mathrm{SiO}_{2} @ 2-\mathrm{MPATD}$ was obtained $236 \mathrm{mg} \mathrm{g}^{-1}$ which was higher than proposed method by Ag-MWCNTs [42]. Also, Krawczyk et al introduced the silver nanoparticles (AgNPs) as solid sorbent for preconcentration and determination of $\mathrm{Hg}^{2+}$ ions in water samples. The limit of detection and RSD\% was achieved $5 \mathrm{ng} \mathrm{L}^{-1}$ and $6-11 \%$, respectively [43].

\section{Conclusions}

In this study, a robust analytical method based on microwave coupled to headspace sorbent trap (HSST) was developed for determination mercury in nail and hair in petrochemical male workers aged 30 to 60 years. Results showed the capacity adsorptions of Ag-MWCNTs and MWCNTs for mercury removal from the air were obtained 205.4 $\mathrm{mg} \mathrm{g}^{-1}$ and $63.7 \mathrm{mg} \mathrm{g}^{-1}$, respectively. It means that mercury removal from the air was increased dramatically by silver nanoparticles pasted on multi-walled carbon nanotubes. After nail/hair digestion, the mercury in liquid phase converted to hydride form $\left(\mathrm{HgH}_{2}\right)$ and captured by silver nanoparticles on MWCNTs as a sorbent trap in head space of separator. The LOD and LOQ of proposed procedure was obtained $5 \mathrm{ng} \mathrm{L}^{-1}$ and 15 ng $\mathrm{L}^{-1}$, respectively. Also, the mean of mercury in nail and hair in workers and control group was achieved $\left(15.2 \pm 3.7 \mu \mathrm{g} \mathrm{g}^{-1} ; 11.6 \pm 2.6 \mu \mathrm{g} \mathrm{g}^{-1}\right)$ and $\left(0.16 \pm 0.05 \mu \mathrm{g} \mathrm{g}^{-1} ; 0.24 \pm 0.03 \mu \mathrm{g} \mathrm{g}^{-1}\right)$, respectively $(\mathrm{RSD}<5 \%)$. Regardless of the interfering factors, the difference between these values is due to high exposure with mercury.

\section{References}

[1] H. Satoh, Occupational and environmental toxicology of mercury and its compounds, Industrial. Health, 38 (2000) 153-164.

[2] B. Zhao, H.H. Yi, X.L. Tang, Q. Li, D.D. Liu, F.Y. Gao, Copper modified activated coke for mercury removal from coal-fired flue gas, Chem. Eng. J., 286 (2016) 585-593.

[3] UN Environment Document Repository, Global mercury modelling: update of modelling results in the global mercury assessment 2013. https://wedocs.unep.org/ handle/20.500.11822/13772, 2015.

[4] Y.S. Gao, Z. Zhang, J.W. Wu, L.H. Duan, A. Umar, L.Y. Sun, Z.H. Guo, Q. Wang, A critical review on the heterogeneous catalytic oxidation of elemental mercury in flue gases, Environ. Sci. Technol., 47 (2013) 1081310823.

[5] S.L. Tang, L.N. Wang, X.B. Feng, Z.H. Feng, R.Y. Li, H.P. Fan, K. Li, Actual mercury speciation and mercury discharges from coalfired power plants in Inner Mongolia, northern China, Fuel, 180 (2016) 194-204. 
[6] M. Sakamoto, N. Tatsuta, K. Izumo, P.T. Phan, L.D. Vu, M. Yamamoto, M. Nakamura, K. Nakai, K. Murata, Health impacts and biomarkers of prenatal exposure to methylmercury: Lessons from Minamata, Japan, Toxic., 6 (2018).

[7] G.J. Zagury, C.-M. Neculita, C. Bastien, L. Deschênes, Mercury fractionation, bioavailability, and ecotoxicity in highly contaminated soils from chlor-alkali plants, Environ. Toxicol. Chem., 25 (2006) 11381147.

[8] C. Feng, Z. Zayas, L. Lima, S. Olivares, D. De La Rosa, S. Berail, E. Tessier, F. Pannier, D. Amouroux, Assessment of $\mathrm{Hg}$ contamination by a chlor-alkali plant in riverine and coastal sites combining $\mathrm{Hg}$ speciation and isotopic signature (Sagua la Grande River, Cuba), J. Hazard. Mater., 371 (2019) 558-65.

[9] L.-n. Liang, J.-b. Shi, B. He, G.-b. Jiang, C.g. Yuan, Investigation of methyl mercury and total mercury contamination in mollusk samples collected from Coastal sites along the Chinese Bohai sea, J. Agric. Food. Chem., 51 (2003) 7373-7378.

[10] C. Gundacker, S. Fröhlich, K. GrafRohrmeister, B. Eibenberger, V. Jessenig, D. Gicic, S. Prinz, K.J. Wittmann, H. Zeisler, B. Vallant, A. Pollak, P. Husslein, Perinatal lead and mercury exposure in Austria, Sci. Total. Environ., 408 (2010) 5744-5749.

[11] S.E. Orr, C.C. Bridges, Chronic kidney disease and exposure to nephrotoxic metals, Int. J. Mol. Sci., 18 (2017).

[12] H. Lohren, J. Bornhorst, R. Fitkau, G. Pohl, H.-J. Galla, T. Schwerdtle, Effects on and transfer across the blood-brain barrier in vitro-Comparison of organic and inorganic mercury species, BMC. Pharmacol. Toxicol., 17 (2016) 63.

[13] G. Genchi, M.S. Sinicropi, A. Carocci, G. Lauria, A. Catalano, Mercury exposure and heart diseases, Int. J. Environ. Res. Public. Health, 14 (2017) 74.

[14] F. Ruggieri, C. Majorani, F. Domanico, A.
Alimonti, Mercury in children: current state on exposure through human biomonitoring studies, Int. J. Environ. Res. Public. Health, 14 (2017).

[15] Centers for Disease Control and Prevention, National biomonitoring program: mercury, 2017. https://www.cdc.gov/biomonitoring/ Mercury_BiomonitoringSummary.html/

[16] X.F. Hu, K. Singh, H.M. Chan, Mercury exposure, blood pressure, and hypertension: A systematic review and dose-response metaanalysis, Environ. Health. Perspect., 126 (2018) 076002.

[17] L.T. Budnik, L. Casteleyn, Mercury pollution in modern times and its socio-medical consequences, Sci. Total. Environ., 654 (2019) 720-734.

[18] M.A. Kamyabi, A. Aghaei, A simple and selective approach for determination of trace $\mathrm{Hg}$ (II) using electromembrane extraction followed by graphite furnace atomic absorption spectrometry, Spectrochim. Acta Part B: At. Spect., 128 (2017) 17-21.

[19] S.L.C. Ferreira, J.P. dos Anjos, C.S.A. Felix, M.M. da Silva Junior, E. Palacio, V. Cerda, Speciation analysis of antimony in environmental samples employing atomic fluorescence spectrometry-Review, Trends. Anal. Chem., 110 (2019) 335-343.

[20] M.-L. Lin, S.-J. Jiang, Determination of As, $\mathrm{Cd}, \mathrm{Hg}$ and $\mathrm{Pb}$ in herbs using slurry sampling electrothermal vaporisation inductively coupled plasma mass spectrometry, Food. Chem., 141 (2013) 2158-2162.

[21] M. Thirumalai, S.N. Kumar, D. Prabhakaran, N. Sivaraman, M.A. Maheswari, Dynamically modified $\mathrm{C} 18$ silica monolithic column for the rapid determinations of lead, cadmium and mercury ions by reversed-phase highperformance liquid chromatography, J. Chromatogr. A, 1569 (2018) 62-69.

[22] S. Wang, X. Song, J. Hu, R. Zhang, L. Men, M. Wei, T. Xie, J. Cao, Direct speciation analysis of organic mercury in fish and kelp by on-line complexation and stacking using 
capillary electrophoresis, Food. Chem., 281 (2019) 41-48.

[23] Y. Wu, X. Wen, Z. Fan, An AIE active pyrene based fluorescent probe for selective sensing $\mathrm{Hg} 2+$ and imaging in live cells, Spectrochim. Acta. A. Mol. Biomol. Spec., 223 (2019) 117315.

[24] A.A. Elezz, H. Mustafa Hassan, H. Abdulla Alsaadi, A. Easa, S. Al-Meer, K. Elsaid, Z.K. Ghouri, A. Abdala, Validation of total mercury in marine sediment and biological samples, using cold vapour atomic absorption spectrometry, Method. Protoc., 1 (2018) 31.

[25] F. Mercader-Trejo, R. Herrera-Basurto, E.R. de San Miguel, J. de Gyves, Mercury determination in sediments by CVAAS after on line preconcentration by solid phase extraction with a sol-gel sorbent containing CYANEX 471X, Int. J. Environ. Anal. Chem., 91 (2011) 1062-1076.

[26] V. Camel, Solid phase extraction of trace elements, Spectrochim. Acta. Part. B: At. Spec., 58 (2003) 1177-1233.

[27] A.E. Visser, R.P. Swatloski, S.T. Griffin, D.H. Hartman, R.D. Rogers, Liquid-liquid extraction of metal ions in room temperature ionic liquids, Sep. Sci. Technol., 36 (2001) 785-804.

[28] W.I. Mortada, I.M.M. Kenawy, Y.G. Abou El-Reash, A.A. Mousa, Microwave assisted modification of cellulose by gallic acid and its application for removal of aluminium from real samples, Int. J. Biol. Macromol., 101 (2017) 490-501.

[29] A.H. El-Sheikh, Y.S. Al-Degs, R.M. AlAs'ad, J.A. Sweileh, Effect of oxidation and geometrical dimensions of carbon nanotubes on $\mathrm{Hg}$ (II) sorption and preconcentration from real waters, Desalination, 270 (2011) 214-220.

[30] G. Luo, H. Yao, M. Xu, X. Cui, W. Chen, R. Gupta, Z. Xu, Carbon Nanotube-Silver Composite for Mercury Capture and Analysis, Energ. Fuels, 24 (2010) 419-426.

[31] H. Shirkhanloo, M. Osanloo, M. Ghazaghi, H. Hassani, Validation of a new and cost-effective method for mercury vapor removal based on silver nanoparticles coating on micro glassy balls, Atmos. Pollut. Res., 8 (2017) 359-365.

[32] Z. Wei, Y. Luo, B. Li, Z. Cheng, J. Wang, Q. Ye, Microwave assisted catalytic removal of elemental mercury from flue gas using $\mathrm{Mn} /$ zeolite catalyst, Atmos. Pollut. Res., 6 (2015) 45-51.

[33] F. Shen, J. Liu, Y. Dong, D. Wu, C. Gu, Z. Zhang, Elemental mercury removal from syngas by porous carbon-supported $\mathrm{CuCl} 2$ sorbents, Fuel, 239 (2019) 138-144.

[34] H. Li, L. Zhu, J. Wang, L. Li, K. Shih, Development of nano-sulfide sorbent for efficient removal of elemental mercury from coal combustion fuel gas, Environ. Sci. Technol., 50 (2016) 9551-9557.

[35] T. Zhu, W. Jing, X. Zhang, W. Bian, Y. Han, T. Liu, Y. Hou, Z. Ye, Gas-phase elemental mercury removal by nano-ceramic material, Nanomater. Nanotechnol., $10 \quad$ (2020) 1847980419899759.

[36] S.-I. Lo, P.-C. Chen, C.-C. Huang, H.-T. Chang, Gold nanoparticle-aluminum oxide adsorbent for efficient removal of mercury species from natural waters, Environ. Sci. Technol., 46 (2012) 2724-2730.

[37] R.S. El-Tawil, S.T. El-Wakeel, A.E. AbdelGhany, H.A.M. Abuzeid, K.A. Selim, A.M. Hashem, Silver/quartz nanocomposite as an adsorbent for removal of mercury (II) ions from aqueous solutions, Heliyon, 5 (2019) $\mathrm{e} 02415$.

[38] W. Marimón-Bolívar, L. Tejeda-Benítez, A.P. Herrera, Removal of mercury (II) from water using magnetic nanoparticles coated with amino organic ligands and yam peel biomass, Environ. Nanotechnol. Monit. Manage., 10 (2018) 486-493.

[39] M. Krawczyk, E. Stanisz, Ultrasound-assisted dispersive micro solid-phase extraction with nano-TiO2 as adsorbent for the determination of mercury species, Talanta, 161 (2016) 384391.

[40] S. Ma, M. He, B. Chen, W. Deng, Q. Zheng, B. 
$\mathrm{Hu}$, Magnetic solid phase extraction coupled with inductively coupled plasma mass spectrometry for the speciation of mercury in environmental water and human hair samples, Talanta, 146 (2016) 93-99.

[41] J. Abolhasani, R. Hosseinzadeh Khanmiri, M. Babazadeh, E. Ghorbani-Kalhor, L. Edjlali, A. Hassanpour, Determination of $\mathrm{Hg}$ (II) ions in sea food samples after extraction and preconcentration by novel Fe3O4@SiO2@ polythiophene magnetic nanocomposite, Environ. Monit. Assess., 187 (2015) 554.

[42] M. Akbar, M. Manoochehri, An efficient 2-mercapto-5-phenylamino-1,3,4-thiadiazole functionalized magnetic graphene oxide nanocomposite for preconcentrative determination of mercury in water and seafood samples, Inorg. Chem. Commun., 103 (2019) 37-42.

[43] M. Krawczyk, E. Stanisz, Silver nanoparticles as a solid sorbent in ultrasound-assisted dispersive micro solid-phase extraction for the atomic absorption spectrometric determination of mercury in water samples, J. Anal. At. Spectrom., 30 (2015) 2353-2358. 